\section{Utilization of the Brazilian public health system by privately insured individuals: a literature review}

\section{Utilização do sistema público de saúde brasileiro por usuários com planos de saúde privados: uma revisão da literatura}

\section{La utilización del sistema público de salud brasileño por la población asegurada por el sistema privado: una revisión de la literatura}

Leonardo Ferreira Fontenelle 1

Thiago Dias Sarti 2

Maria Beatriz Junqueira de Camargo 3

Ethel Leonor Noia Maciel 2

Aluísio J. D. Barros 1

\begin{abstract}
More than one in four Brazilians have private health insurance (PHI), even thought it covers mostly the same procedures as the Brazilian Unified $\mathrm{Na}$ tional Health System (SUS). This literature review included articles and monographs published since 1990 about the utilization of SUS by privately insured individuals. Considering outpatient care and hospitalization, privately insured people in Brazil use SUS in approximately 13\% of the times they receive health care, and approximately $7 \%$ of people receiving care paid by SUS are privately insured; these findings vary depending on the type of service studied and on study methods. Utilization of SUS is more frequent in less developed regions, by people with more restricted PHI plans and by people with worse health status. Privately insured people report the limitations of PHI plans as their reasons for resorting to SUS. Sometimes, beneficiaries of PHI plans owned by nonprofit hospitals (which also provide health care financed by SUS) have easier access to care than uninsured people financed by SUS. Anecdotally, privately insured people are satisfied with SUS, but not to the point of adopting SUS as their preferred source of care. In short, for privately insured people, SUS only plays a secondary role in their health care. Despite PHI taking over part of the SUS's health care demand, PHI represents a restriction of the universal, equitable character of the SUS.
\end{abstract}

Unified Health System; Health Insurance; Delivery of Health Care;

Health Services

\section{Correspondence}

L. F. Fontenelle

Programa de Pós-graduação em Epidemiologia, Universidade Federal de Pelotas.

Rua Marechal Deodoro 1160, 3o piso, Pelotas, RS 96020-220, Brasil.

leonardof@leonardof.med.br

1 Programa de Pós-graduação em Epidemiologia, Universidade Federal de Pelotas, Pelotas, Brasil.

2 Centro de Ciências da Saúde, Universidade Federal do Espírito Santo, Vitória, Brasil.

3 Faculdade de Odontologia, Universidade Federal de Pelotas, Pelotas, Brasil. 


\section{Introduction}

Brazil is one of the few countries where private health insurance (PHI) accounts for more than 20\% of health care expenditure 1. According to the World Health Organization's Global Health Expenditure Database (GHED), PHI's share in health expenditure increased gradually from 18.2\% in 1995 to $26.8 \%$ in 2014. In 2013, 27.9\% of the Brazilians had PHI, which paid for 29.2\% of the utilization of health care 2. Brazil also has a national health system called Brazilian Unified National Health System (SUS, in Portuguese), which is universal, financed by government taxes and free at the point of care. In 2013 , SUS paid for $59.9 \%$ of the utilization of health care 2 , while $14.9 \%$ of users had to pay for it out-of-pocket 2 .

In Brazil, PHI is called "supplementary health" 3. Indeed, PHI has a supplementary role, according to the Organization for Economic Co-operation and Development's (OECD) taxonomy 4, as it covers hospital amenities not available to most of the population. On the other hand, PHI mostly covers services already available through SUS, by providing enhanced access to its users and allowing them to choose health care providers. Thus, in Brazil PHI plays essentially a duplicate role 5.

Counter-intuitively, privately insured people in the OECD countries continue to use public health services even if their PHI already cover them ${ }^{4}$. PHI often controls the utilization of its services through co-payments or other "cost-sharing" mechanisms 4, thus contributing less to the demand satisfaction for public services, especially if the public services are free at the point of care. PHI also induces the use of the public sector because private treatments may generate demand for prescription drugs paid by the public sector ${ }^{4}$.

Considering the uncertainties on the issue, we performed a systematic search and (narrative) review on the utilization of SUS by privately insured individuals in Brazil.

\section{Methods}

Studies were included in this literature review if they were published as articles in peer-reviewed periodicals or as monographs (masters' thesis or doctoral dissertations), describing original quantitative or qualitative empirical research on the utilization of public health care services by privately insured individuals (except for people with PHI policies covering only dental care). We focused on the utilization of SUS as a health care provider, thus excluding studies on diagnostic and therapeutic support (e.g., clinical pathology, radiology) or drug therapy provision (patients obtaining medicines at the pharmacy). We restricted our selected to studies in Portuguese, English or Spanish published since 1990, the year when Brazil's Organic Health Law was established.

The search was performed on January 2017 by including several databases. Through the Virtual Health Library (VHL; https://bvsalud.org/en/), we searched in the LILACS and other available databases, except for MEDLINE. Through Web of Science (https://apps.webofknowledge.com), we searched in Science Citation Index Expanded (SCI-EXPANDED), Social Sciences Citation Index (SSCI) and SciELO Citation Index. We also used searched PubMed (https://www.ncbi.nlm.nih.gov/ pubmed/) and IDEAS (https://ideas.repec.org/) to search for MEDLINE and RePEc studies.

The search strategy for MEDLINE, RePEc, SCI-EXPANDED and SSCI was similar to (("health insurance" OR "group practice" OR "private health plan" OR "private health plans" OR "health insurer" OR "private health company" OR "self-management" OR "medical cooperative" OR "group medicine" OR "health maintenance organization” OR "health maintenance organizations” OR "philanthropy" OR "health benefit plan” OR "health benefit plans”) OR “utilization”) AND ((“Unified Health System” OR “Sistema Único de Saúde”) OR ("Brazil” OR "Brasil”)), with the above-mentioned restrictions by language, publication type and publication year (detailed search strategies can be found in the Supplementary Material; http://cadernos.ensp.fiocruz.br/site/public_site/arquivo/suppl-e00004118_2644. pdf). For VHL and the SciELO Citation Index, the keywords and text words referring to Brazil were omitted: (("health insurance” OR ... OR "health benefits plans”) OR (utilization AND ("Unified Health System” OR "Sistema Único de Saúde” OR “SUS”))); and the restrictions were the same. Whenever possible, adequate keywords were included in the search strategy. 
The citations retrieved were consolidated in a single database, and duplicates were identified and removed. Two authors (L.F.F. and T.D.S.) screened the titles and abstracts of the cited publications and then verified their full-text for eligibility. While screening titles and abstracts for eligibility, disagreement between the authors was solved by verifying the full-text. Any disagreement after this verification was solved by consensus or, if necessary, by another author (M.B.J.C.).

L.F.F. searched for additional citations in Capes' Theses and Dissertation Database (https://cata logodeteses.capes.gov.br), in two compendiums of research on health economics in Brazil 6,7, in the reference lists of the selected documents, and in Web of Science (for new articles citing those already included). These additional documents had their reference lists and citing articles scanned as well, until no new eligible document was found. In this process, monographs were replaced by their corresponding articles if they had been published already.

The abstraction of the studies' findings was conducted by L.F.F. and verified by T.D.S. The eligible studies were characterized based on study population, study design and their authors' disclosed bias or potential conflicts of interest. Using a pre-tested form, findings on the utilization of SUS by privately insured people were categorized as "frequency of utilization", "reasons and correlates of utilization", "means of access" (e.g., in sites providing health care through both SUS and PHI) and "outcomes of utilization" (e.g., user's satisfaction). In the category "frequency of utilization", the findings emphasized the proportion of privately insured people using SUS at a reference period (and the corresponding prevalence ratio compared to uninsured people) as well as the proportion of privately insured people among users of SUS; these indicators were calculated when necessary. Because of the heterogeneity of studies, these indicators were tabulated in the Supplementary Material (http://cadernos.ensp.fiocruz. br/site/public_site/arquivo/suppl-e00004118_2644.pdf). In the category "reasons and correlates of utilization", findings from quantitative studies emphasized contextual, socioeconomic, demographic, PHI-related or health-related variables ("correlates"), explaining variability in the proportion of privately insured people using SUS; whereas findings from qualitative studies emphasized the reasons presented by privately insured people for utilization of SUS. As the differences in the objectives and methods made it impossible to use a single standard, we opted for discussing the robustness of the review as a whole instead of assessing the quality of each study.

This literature review was registered in the PROSPERO database under number CRD420170 57094.

\section{Results}

The search strategy identified 3,977 citations through VHL, 659 through PubMed, 8 (RePEc) through IDEAS, and 247 (SCI-EXPANDED and SSCI) and 206 (SciELO Citation Index) through Web of Science, totaling 4,119 unique citations (Figure 1). From these, 75 citations remained after the screening of titles and abstracts, and 27 citations remained after examining the full versions of the texts for eligibility. Complementary searches found six additional studies, and we substituted three monographs by their corresponding articles (two of which had already been retrieved through the search strategy). In the end, we included 31 studies in the review.

Authors have published these studies between 1999 and 2017 (median: 2009) 5,8,9,10,11,12,13,14,15,16, $17,18,19,20,21,22,23,24,25,26,27,28,29,30,31,32,33,34,35,36,37$ (Table 1). The authors of five studies reported having no conflicts of interest 19,28,31,33,35, while in the other studies the authors did not disclose whether they had any conflicts of interest, nor did they examine interviewers' biases (in qualitative studies).

While some studies had national coverage 5,12,13,14,22,24,25, others covered certain geographical regions (e.g., Northeast or Southeast) 8,11,15,20,26, states 16,33, metropolitan areas 9,17,18, municipalities $10,19,21,23,27,28,30,31,34,35,36,37$ or parts of a municipality 22,32 . The study population included varied age groups, but most of them showed a balanced gender composition, with the exception of one study about men's health 37 and two about women's health 19,31. In the quantitative studies, the proportion of privately insured people ranged from $5.7 \% 35$ to $70.7 \% 27$, while in the qualitative studies all participants were privately insured $9,15,20,26$.

In most quantitative studies, participants were sampled through household surveys, such as Equity-LA 33; Health, Well-being and Aging (SABE, in Portuguese) 28; Brazilian National Household Sample 
Figure 1

Flow diagram of the systematic search.

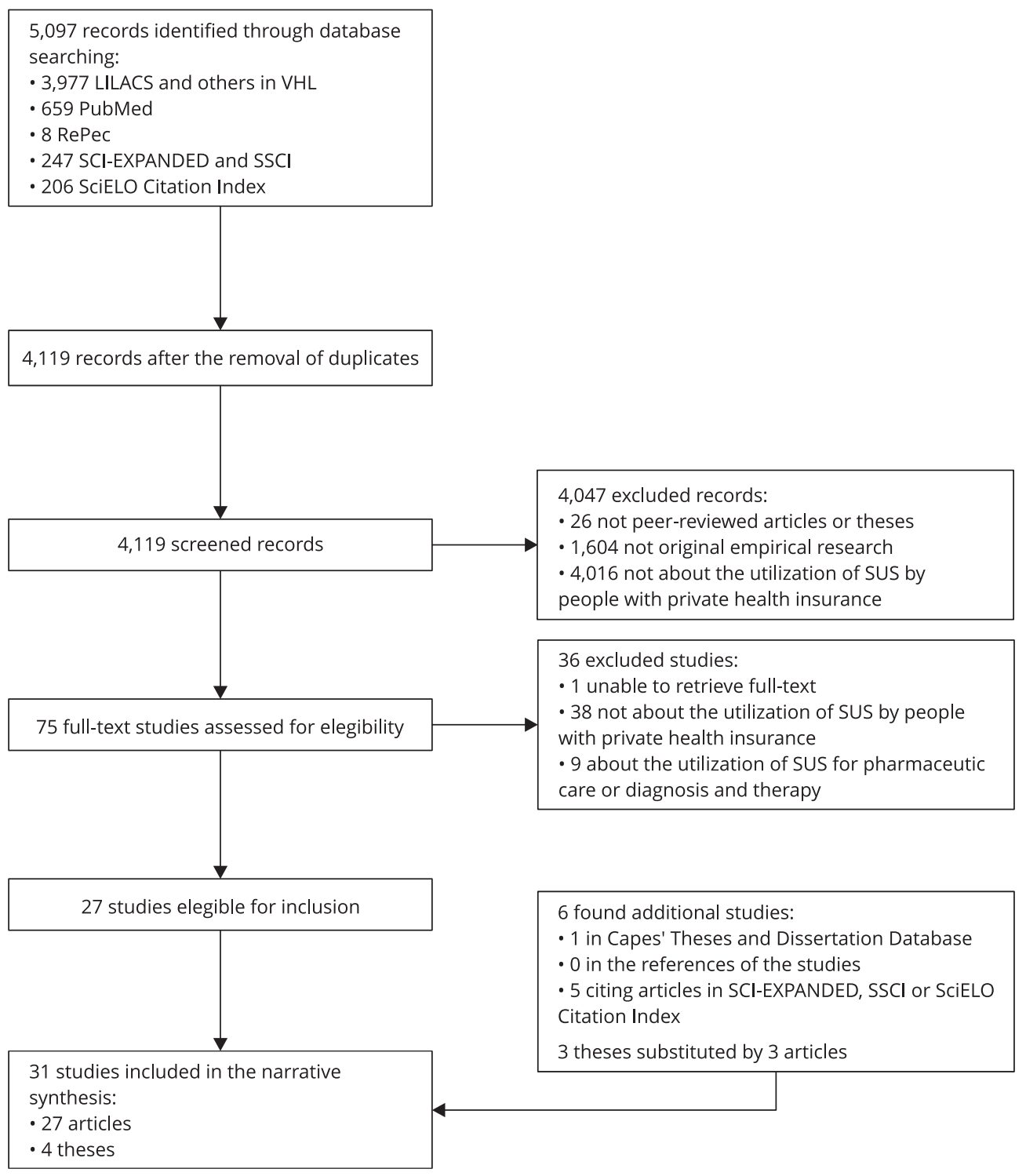

SUS: Brazilian Unified National Health System.

Survey (PNAD, in Portuguese) 5,12,14,22,24,25; World Health Survey (WHS) 13; Living Standards Survey (PPV, in Portuguese) 8,11; Health Survey in Campinas (ISACamp, in Portuguese) 31; Health and Diet Survey Capital (ISA-Capital, in Portuguese) 34; and Survey of Living Conditions (PCV, in Portuguese) 16,17,18, among others 10,21,37. Other quantitative studies sampled patients from the Family Health Strategy (FHS) registry 23,27,29,32,35 or from utilization of health service 19,30,36. A quantitative study 8 included data from an opinion poll whose methods we could not verify. In qualitative studies including patients 15,20,26, participants undergone intentional or snowballing sampling, based on the utilization of health services, participation in support groups or patients association groups or from the Brazilian Information System on Live Births (SINASC, in Portuguese); data were collected through focus 
Table 1

Characteristics of the included studies.

\begin{tabular}{|c|c|c|c|}
\hline Study (year) & Study population & PHI coverage & Design \\
\hline \multirow[t]{2}{*}{ Bahia 8 (1999) } & Utilization of health services, 1998 & Unknown & Opinion poll by IBOPE \\
\hline & $\begin{array}{l}\text { PPV 1996/1997: resident population of Northeast and Southeast regions in } \\
\qquad 1996-1997\end{array}$ & Unknown & $\begin{array}{l}\text { Household survey with } \\
\text { cluster sampling }\end{array}$ \\
\hline Santos 9 (2000) & $\begin{array}{l}\text { Human resources managers of three large chemical-petrochemical } \\
\text { industries in the ABC Paulista metropolitan area (São Paulo State), and } \\
\text { occupational physician of one of them. Data is about the direct employees, } \\
\qquad 80-95 \% \text { of whom were male }\end{array}$ & $\begin{array}{l}\text { All direct employees } \\
\text { had employer- } \\
\text { sponsored PHI }\end{array}$ & In-depth interview \\
\hline $\begin{array}{l}\text { Silva et al. } 10 \\
(2000)\end{array}$ & $\begin{array}{l}\text { Infant (under one year of age) residents of the Embu das Artes municipality } \\
\qquad \text { (São Paulo State) }\end{array}$ & $29.4 \%$ & $\begin{array}{l}\text { Household survey with } \\
\text { cluster sampling }\end{array}$ \\
\hline $\begin{array}{l}\text { Travassos et al. } 11 \\
(2000)\end{array}$ & $\begin{array}{l}\text { PPV 1996/1997: resident population of Northeast and Southeast regions in } \\
\qquad 1996-1997\end{array}$ & Unknown & $\begin{array}{l}\text { Household survey with } \\
\text { cluster sampling }\end{array}$ \\
\hline $\begin{array}{l}\text { Farias \& } \\
\text { Melamed } 12 \\
(2003)\end{array}$ & $\begin{array}{l}\text { PNAD 1998: resident population in Brazil in } 1998 \text { (except for the rural area of } \\
\text { the North Region but including the rural area of Tocantins State) }\end{array}$ & $24.5 \%$ & $\begin{array}{l}\text { Household survey with } \\
\text { cluster sampling }\end{array}$ \\
\hline $\begin{array}{l}\text { Viacava et al. } 13 \\
\text { (2005) }\end{array}$ & $\begin{array}{l}\text { WHS 2003: adult (18+ years) resident population in Brazil in } 2003 \text { (except for } \\
\text { the rural area of the North Region but including the rural area of Tocantins } \\
\text { State) }\end{array}$ & $24.2 \%$ & $\begin{array}{l}\text { Household survey with } \\
\text { cluster sampling }\end{array}$ \\
\hline $\begin{array}{l}\text { Ribeiro et al. } 14 \\
\text { (2006) }\end{array}$ & $\begin{array}{l}\text { PNAD 2003: resident population in Brazil in } 2003 \text { (except for the rural area of } \\
\text { the North Region but including the rural area of Tocantins State) }\end{array}$ & $24.6 \%$ & $\begin{array}{l}\text { Household survey with } \\
\text { cluster sampling }\end{array}$ \\
\hline $\begin{array}{l}\text { Gerschman } \\
\text { et al. } 15 \text { (2007) }\end{array}$ & $\begin{array}{l}\text { Beneficiaries of PHI plans owned by nonprofit hospitals in the states of } \\
\text { São Paulo (three in the metropolitan area and three in the interior), Rio de } \\
\text { Janeiro (one in the metropolitan area and two in the interior) and Minas } \\
\text { Gerais (one in the metropolitan area). Average age } 50 \text { years, with two or } \\
\text { three dissatisfied participants and preferably at least one mother of small } \\
\text { children per group }\end{array}$ & $\begin{array}{l}\text { Among the ten PHI } \\
\text { plans, three were not } \\
\text { registered with ANS, } \\
\text { and one was actually } \\
\text { a discount card }\end{array}$ & $\begin{array}{l}\text { Focus groups with } \\
\text { participants recruited at } \\
\text { the hospitals' entrance }\end{array}$ \\
\hline $\begin{array}{l}\text { Pessoto et al. } 16 \\
\text { (2007) }\end{array}$ & $\begin{array}{l}\text { Resident population of the urban area of five municipalities (São Paulo, } \\
\text { Santo André, Osasco, Franco da Rocha, and Guarulhos) holding most of the } \\
\text { population and health services of São Paulo State. Subset of PCV } 1998\end{array}$ & $46.1 \%$ & $\begin{array}{l}\text { Household survey with } \\
\text { cluster sampling }\end{array}$ \\
\hline Barata 17 (2008) & $\begin{array}{l}\text { Resident population of the urban area of the São Paulo metropolitan area. } \\
\qquad \text { Subset of PCV } 2006\end{array}$ & $36.8 \%$ & $\begin{array}{l}\text { Household survey with } \\
\text { cluster sampling }\end{array}$ \\
\hline $\begin{array}{l}\text { Barreto Jr. et al. } 18 \\
(2008)\end{array}$ & $\begin{array}{l}\text { Resident population of the urban area of the São Paulo metropolitan area. } \\
\qquad \text { Subset of PCV } 2006\end{array}$ & $36.8 \%$ & $\begin{array}{l}\text { Household survey with } \\
\text { cluster sampling }\end{array}$ \\
\hline $\begin{array}{l}\text { Barros et al. } 19 \\
(2008)\end{array}$ & $\begin{array}{l}\text { Mothers living in the urban area of the municipality of Pelotas or the } \\
\text { neighboring district of Jardim América (Rio Grande do Sul State) giving birth } \\
\text { in Pelotas' hospitals in } 2004 \text {. Subset of the } 2004 \text { Pelotas Birth Cohort }\end{array}$ & $34.0 \%$ & Birth cohort \\
\hline $\begin{array}{l}\text { Conill et al. } 20 \\
(2008)\end{array}$ & $\begin{array}{l}\text { PHI beneficiaries in the municipality of Florianópolis (Santa Catarina State) } \\
\text { with acute myocardial infarction, breast cancer, alcoholism or (up to 11/2 } \\
\text { years before) birth. Mostly women, with complete secondary or higher } \\
\text { education and monthly income greater than BRL 2,000 }\end{array}$ & $100.0 \%$ & $\begin{array}{l}\text { In-depth interview } \\
\text { with thematic analysis, } \\
\text { intentional or snowball } \\
\text { sampling from hospitals } \\
\text { or patient organizations }\end{array}$ \\
\hline $\begin{array}{l}\text { Santos et al. } 5 \\
(2008)\end{array}$ & $\begin{array}{l}\text { PNAD 2003: resident population in Brazil in } 2003 \text { (except for the rural area of } \\
\text { the North Region but including the rural area of Tocantins State) }\end{array}$ & $24.6 \%$ & $\begin{array}{l}\text { Household survey with } \\
\text { cluster sampling }\end{array}$ \\
\hline $\begin{array}{l}\text { Fernandes } \\
\text { et al. } 21 \text { (2009) }\end{array}$ & $\begin{array}{l}\text { Resident population in the catchment area of FHS in the urban area of the } \\
\text { municipality of Porto Alegre (Rio Grande do Sul State), } 2003\end{array}$ & $21.9 \%$ & Household survey \\
\hline Oliveira 22 (2009) & $\begin{array}{c}\text { PNAD } 1998 \text { and 2003: resident population in Brazil in } 1998 \text { and } 2003 \\
\text { (except for the rural area of the North Region but including the rural area of } \\
\text { Tocantins State) }\end{array}$ & $\begin{array}{l}24.5 \%(1998) ; 24.6 \% \\
(2003)\end{array}$ & $\begin{array}{l}\text { Household survey with } \\
\text { cluster sampling }\end{array}$ \\
\hline $\begin{array}{l}\text { Pereira et al. } 23 \\
(2010)\end{array}$ & $\begin{array}{l}\text { Elderly (60+ years) population in the municipality of Teixeira (Minas Gerais } \\
\qquad \text { State) in } 2004\end{array}$ & $29.9 \%$ & $\begin{array}{l}\text { Survey in the household } \\
\text { with sampling based on } \\
\text { the SIAB, which included } \\
\text { the whole municipality }\end{array}$ \\
\hline
\end{tabular}

(continues) 
Table 1 (continued)

\begin{tabular}{|c|c|c|c|}
\hline Study (year) & Study population & PHI coverage & Design \\
\hline $\begin{array}{l}\text { Porto et al. } 24 \\
(2011)\end{array}$ & $\begin{array}{l}\text { PNAD 1998, } 2003 \text { and 2008: resident population in Brazil in } 1998 \text { (except for } \\
\text { the rural area of the North Region but including the rural area of Tocantins } \\
\text { State), } 2003 \text { (idem) and } 2008\end{array}$ & $\begin{array}{l}24.5 \%(1998) ; 24.6 \% \\
(2003) ; 25.9 \%(2008)\end{array}$ & $\begin{array}{l}\text { Household survey with } \\
\text { cluster sampling }\end{array}$ \\
\hline $\begin{array}{l}\text { Silva et al. } 25 \\
\text { (2011) }\end{array}$ & $\begin{array}{l}\text { PNAD } 2003 \text { and 2008: resident population in Brazil in } 2003 \text { (except for the } \\
\text { rural area of the North Region but including the rural area of Tocantins } \\
\text { State) and } 2008\end{array}$ & $\begin{array}{l}24.5 \%(1998) ; 24.6 \% \\
(2003)\end{array}$ & $\begin{array}{l}\text { Household survey with } \\
\text { cluster sampling }\end{array}$ \\
\hline $\begin{array}{l}\text { Sisson et al. } 26 \\
(2011)\end{array}$ & $\begin{array}{l}\text { PHI beneficiaries in the municipalities of Porto Alegre, Florianópolis and } \\
\text { Curitiba (capitals of the states of Rio Grande do Sul, Santa Catarina and } \\
\text { Paraná, respectively) in } 2008 \text {, with acute myocardial infarction, breast } \\
\text { cancer, alcoholism or (up to } 1 \frac{1}{2} \text { year before) birth }\end{array}$ & $100.0 \%$ & $\begin{array}{l}\text { In-depth interview } \\
\text { with thematic analysis, } \\
\text { intentional or snowball } \\
\text { sampling from hospitals, } \\
\text { primary care centers, } \\
\text { SINASC and patient } \\
\text { organizations }\end{array}$ \\
\hline $\begin{array}{l}\text { Bousquat et al. } 27 \\
(2012)\end{array}$ & $\begin{array}{l}\text { Population assigned to the "most typical" primary care center of the Santo } \\
\text { André municipality (São Paulo State), 2005-2006 }\end{array}$ & $70.7 \%$ & $\begin{array}{l}\text { Survey in the household } \\
\text { with sampling based on } \\
\text { the SIAB }\end{array}$ \\
\hline $\begin{array}{l}\text { Hernandes } \\
\text { et al. } 28 \text { (2012) }\end{array}$ & $\begin{array}{l}\text { SABE 2006: elderly (60+ years) living in the municipality of São Paulo (São } \\
\text { Paulo State) in } 2006\end{array}$ & Approximately 40\% & $\begin{array}{l}\text { Household survey with } \\
\text { cluster sampling }\end{array}$ \\
\hline $\begin{array}{l}\text { Oliveira et al. } 29 \\
\text { (2012) }\end{array}$ & $\begin{array}{l}\text { Adults (20-75 years) living in the catchment area of two primary care centers } \\
\text { in the Liberdade health district, in the municipality of Salvador (Bahia State), } \\
2009-2010\end{array}$ & $10.8 \%$ & $\begin{array}{l}\text { Survey in the household } \\
\text { with sampling based on } \\
\text { the SIAB }\end{array}$ \\
\hline $\begin{array}{l}\text { Pires et al. } 30 \\
(2013)\end{array}$ & $\begin{array}{l}\text { Users of primary care centers and of emergency care units in the Belo } \\
\text { Horizonte municipality (Minas Gerais State), } 2008\end{array}$ & $46.7 \%$ & $\begin{array}{l}\text { Survey with sampling of } \\
\text { consultations }\end{array}$ \\
\hline $\begin{array}{l}\text { Amorim \& } \\
\text { Barros } 31 \text { (2014) }\end{array}$ & $\begin{array}{l}\text { Adult women (20-59 years) living in the urban area of the Campinas } \\
\text { municipality (São Paulo State), 2008. Subset of ISACamp } 2008\end{array}$ & $46.4 \%$ & $\begin{array}{l}\text { Household survey with } \\
\text { cluster sampling }\end{array}$ \\
\hline $\begin{array}{l}\text { Bonello \& } \\
\text { Corrêa } 32 \text { (2014) }\end{array}$ & $\begin{array}{l}\text { Adults (18+ years) assigned to the Américo Bertão primary care center, in the } \\
\text { Cordeirópolis municipality (São Paulo State), in } 2011\end{array}$ & $44.6 \%$ & $\begin{array}{l}\text { Survey in the household } \\
\text { with sampling based on } \\
\text { the SIAB }\end{array}$ \\
\hline $\begin{array}{l}\text { Garcia-Subirats } \\
\text { et al. } 33 \text { (2014) }\end{array}$ & $\begin{array}{l}\text { Resident population of the Caruaru municipality and the } 3.2 \text { and } 3.3 \text { health } \\
\text { districts of the Recife municipality (Pernambuco State) in } 2011 \text {, with a health } \\
\text { problem or seeking health care in the last three months }\end{array}$ & $20.1 \%$ & $\begin{array}{l}\text { Household survey with } \\
\text { cluster sampling }\end{array}$ \\
\hline Olsen 34 (2014) & $\begin{array}{l}\text { ISA-Capital 2008: Resident population of the urban area of the São Paulo } \\
\text { municipality (São Paulo State) in } 2008\end{array}$ & $46.2 \%$ & $\begin{array}{l}\text { Household survey with } \\
\text { cluster sampling }\end{array}$ \\
\hline $\begin{array}{l}\text { Santiago et al. } 35 \\
(2014)\end{array}$ & $\begin{array}{l}\text { Children aged 5-9 years living in the Sobral municipality (Ceará State) in } \\
\qquad 1999-2000\end{array}$ & $5.7 \%$ & $\begin{array}{l}\text { Survey in the household } \\
\text { with sampling based on } \\
\text { the SINASC }\end{array}$ \\
\hline $\begin{array}{l}\text { Zanon et al. } 36 \\
(2016)\end{array}$ & $\begin{array}{l}\text { Adults (18+ years) using emergency care units in the municipality of Serra } \\
\text { (Espírito Santo State) for less urgent or nonurgent care at work hours, in } \\
2014\end{array}$ & $14.6 \%$ & $\begin{array}{l}\text { Survey with consecutive } \\
\text { sampling of users }\end{array}$ \\
\hline $\begin{array}{l}\text { Arruda et al. } 37 \\
\text { (2017) }\end{array}$ & $\begin{array}{l}\text { Adult men (20-59 years) living in the Maringá municipality (Paraná State) in } \\
\qquad 2013 \text { who use/have used any kind of health service }\end{array}$ & $48.0 \%$ & $\begin{array}{l}\text { Household survey with } \\
\text { cluster sampling }\end{array}$ \\
\hline
\end{tabular}

ANS: Brazilian National Regulatory Agency for Private Health Insurance and Plans; FHS: Family Health Strategy; IBOPE: Brazilian Institute of Public Opinion and Statistics; ISACamp: Health Survey in Campinas; ISA-Capital: Health and Diet Survey - Capital; PCV: Survey of Living Conditions;

PHI: private health insurance; PNAD: Brazilian National Household Sample Survey; PPV: Living Standards Survey; SABE: Health, Well-being and Aging; SIAB: Primary Health Care Information System; SINASC: Brazilian Information System on Live Births; WHS: World Health Survey.

Note: studies 19,28,31,33,35 reported having no conflicts of interest but the others did not disclose whether there was a conflict of interest; no qualitative study clarified the interviewers' biases. 
groups 15 or in-depth interviews 20,26 . Another qualitative study 9 included human resources managers of large industries indicated by trade union leaders, but the collected data concerned all the industries' direct employees.

\section{Frequency of utilization}

By the end of the 20th century, the first studies on the frequency of utilization of SUS by privately insured people already evidenced their preference for using private health services instead of public $8,9,11$. In 2003 and 2008, SUS paid for the health care of 11.8 to $13.8 \%$ of privately insured people in Brazil, resulting in prevalence ratios (PR) of 0.12 to 0.17 when compared to the utilization of SUS by uninsured people 5,14,25. Furthermore, $23.1 \%$ of privately insured men in a municipality reported having SUS as their usual source of care (PR: 0.26) in 200337.

Conversely, the prevalence of PHI among those using SUS was $7.2 \%$ in Brazil by 2003, while in the general population this prevalence was $24.6 \%$ 5,14. In São Paulo's metropolitan area, by 2006 , the prevalence of PHI among users of SUS and in the general population was respectively $12.8 \%$ and $36.8 \% 17,18$.

Regarding outpatient care, SUS paid for the health care of 9.6\% privately insured people by 1998 (PR: 0.11) and of $12.3 \%$ by 2003 (PR: 0.14) 22. This proportion was larger in a study with a longer recall period (12 months, instead of 15 days) (18.1\%, PR: 0.24$) 13$ as well as for high-complexity procedures (27.3\%) 22 and antenatal visits (20.2\%; PR: 0.23) ${ }^{13}$. In studies with smaller geographic coverage areas (state, municipality) and focusing on different subtypes of outpatient care, the proportion of privately insured people having their health care utilization paid by SUS ranged from 3.9\% to 24.4\% (PR: 0.05 to 0.51) $16,18,21,29,31,33,34$, with the exception of the near exclusive utilization of SUS for vaccines offered through SUS' National Immunization Program (PNI, in Portuguese) 34 . Among these studies, the proportion was higher and the PR lower if the indicator was the use of a particular health service at least once in the recall period, instead of reporting whether SUS paid for the last time the participant used a subtype of outpatient care. Other studies of smaller geographic coverage reported the proportion of privately insured people who considered themselves users of the SUS' primary care center of their community; this proportion ranged from $14.8 \%$ to $88.8 \%$ (PR: 0.27 to 0.96 ) 10,23,27,32,33,35.

Conversely, the prevalence of PHI among people using SUS for outpatient care in Brazil ranged from $6.7 \%$ to $8.2 \%$ in $1998-2008$, while for the general population this prevalence ranged from $24.2 \%$ to $25.9 \% 13,22,24$. Both proportions had an upward tendency during the period. The prevalence of PHI was lower among people using SUS for medical consultations (6.5\%) 22 or antenatal care (5.1\%) 13 , and higher among people using SUS for high-complexity procedures (11.6\% in 2003, $12.8 \%$ in 2008) 22,24, pharmaceutical care (not drug therapy provision) $(11.2 \%)^{5}$, and "vaccination, injection or emergency care” (11\%) 5,22. Prevalence of PHI was also higher among users of SUS' primary care centers and/or emergency centers, in studies with smaller geographic coverage areas: $30.4 \%$ (compared to $46.7 \%$ for the general population) 30 and $14.6 \%$ (compared to $37.3 \%$ for the general population) 36 .

Concerning hospitalizations, SUS paid for the health care of 13\% of people with PHI by 1998 (PR: 0.14 ) and $15.7 \%$ by 2003 (PR: 0.18) 5,12,22. This proportion was larger for giving birth (20.2\% to $29.0 \%$; PR: 0.23$) 13,19,22$, and smaller for a survey conducted in the city of São Paulo by 2008 ( $7 \%$ to $9.5 \%$, depending on the subtype of hospitalization; PR: 0.07 to 0.10 ).

Conversely, the prevalence of PHI among people using SUS for hospitalization ranged from 5.7\% to $7.2 \%$ in $1998-2008$, while for the general population, this prevalence ranged from $24.2 \%$ to $25.9 \%$ $5,13,22,24$; these proportions showed an upward tendency during the period. The prevalence of PHI was higher in hospitalizations for cesarean section, surgery and diagnostic exams, ranging from $7.4 \%$ to $9 \%$ 5,24; and lower in hospitalizations for psychiatric treatment, clinical treatment, vaginal delivery or any birth, ranging from $4.2 \%$ to $6 \% 5,13$. Among the older population of the city of São Paulo, by 2006, the prevalence of PHI was of $17.9 \%$ among people using SUS for any hospitalization, and approximately $40 \%$ overall 28 . 


\section{Reasons and correlates of utilization}

Both for outpatient care and hospitalization, the utilization of SUS by privately insured people was more frequent in less developed geographic regions and outside the metropolitan areas; for PHI policies with a smaller geographic coverage area, with smaller premiums, with co-payment and not covering the procedure; and among people with poorer health 18,22. Notwithstanding the lack of a more sophisticated statistical analysis of these correlates, these findings have been explained by the respective study authors as indicating more restrictive PHI policies and less developed provider networks 18,22 .

The reasons privately insured people gave for using SUS - obtaining access to occupational medicine, getting a sickness certificate (for alcoholism, a tracer condition for mental health) and receiving emergency care (for acute myocardial infarction, a tracer condition for noncommunicable diseases) - included the lack of the health service in the PHI's provider network or the belief that the plan did not cover the procedure 9,20,26. In nonprofit hospitals having their own PHI plan despite belonging to SUS' provider network, people reported using SUS because their PHI policies required long waiting periods or did not cover the procedure 15.

\section{Means of access}

The last mentioned study also described how people with a nonprofit hospital's PHI policy accessed SUS within the same hospital. When privately insured people could not get their insurer to pay for a hospitalization or a specific procedure, they would seek SUS by regular means or, in case of a close relation to the hospital's administration, they would get preferential access to SUS within the hospital 15. Sometimes it was not clear for the privately insured individual whether SUS or the insurer was going to pay for the hospitalization, and sometimes paying for PHI was a way of guaranteeing preferential access to hospital care paid by SUS 15 .

In a quantitative study about utilization of primary care centers that implemented FHS in a particular health district of the city of Salvador, 62\% of people with PHI seeking for health care ended up obtaining it, compared to percentage of $80.4 \%$ for uninsured people (PR: $0.77, \mathrm{p}<0.001$ ); the authors did not elaborate on this apparent pro-uninsured difference 29.

\section{Outcomes of utilization}

In one qualitative study on the satisfaction of privately insured people with their health care itineraries for four tracer conditions (myocardial infarction, breast cancer, childbirth and alcoholism), those with myocardial infarction hospitalized by SUS were satisfied with their experience ${ }^{26}$. On the other hand, these people have been transferred to a hospital in their PHI's provider network as soon as possible 20 .

\section{Discussion}

As one might expected, the studies show that privately insured people use SUS for a minority of their needs. Considering outpatient care and hospitalization together, privately insured people in Brazil use SUS 11.8 to $13.8 \%$ of the times they receive health care, and $7.2 \%$ of people who receive care paid by SUS are privately insured. Meanwhile, uninsured people use SUS for most of their health care. The difference between privately insured people and the uninsured ones varies depending on the type and subtype of health care under study and on the study methods. Naturally, this difference was lower in studies assessing frequency of utilization of SUS for longer periods, e.g. studies on people who reported being users of SUS, or having used the service at least once in the previous many months; it was also lower among people assigned to an FHS team. In addition, the estimate of the difference was less precise in smaller studies, resulting in a few cases of no statistical significance. Due to the heterogeneity of methods in the included studies, we did not carry out a meta-analysis. 
Both quantitative studies on the correlates and the qualitative studies on the reasons for utilization agree that utilization of SUS by privately insured individuals stems from the restrictiveness of their PHI policies and the scarcity of their PHI's provider networks. On the other hand, studies found copayment to be a correlate but not a reason; and they did not report quality of care as a correlate or as a reason for the utilization of SUS.

In nonprofit hospitals with their own PHI plan despite belonging to SUS's provider network, privately insured people do not always access SUS through regular means. Sometimes the nonprofit hospital's PHI plan works effectively as a way to obtain preferential access within the hospital to health services paid by SUS, and sometimes it is not clear for the privately insured individual if their health care is whether paid by SUS or their insurer. On the other hand, privately insured people might have less access to primary care centers, although the generalizability and explanation of this finding are uncertain.

Being hospitalized in SUS seems to be satisfactory to privately insured people, at least for acute myocardial infarction in the capitals of the South. This satisfaction, however, was a unique finding, and did not result in preference for the public hospital rather than the private one. No study here included have addressed other health care utilization outcomes, such as clinical recovery, acquisition or loss of PHI or health expenditure from any perspective.

One strength of this review is the comprehensiveness of its search strategy and the large number of relevant databases searched. This comprehensiveness allowed the inclusion of studies approaching the theme in many ways, which were unlikely to be found by a more focused search strategy. Another strength is the coherence of the findings among the studies, despite differences in study population or design, thus increasing our confidence in the validity of these findings. Finally, the absence of conflicts of interest, together with the agreement between the studies reporting having no conflicts of interest and those without such disclosure, suggests the findings of this review were not biased by conflicts of interest.

On the other hand, the observational and cross-sectional aspects of the quantitative studies included in the review demand a careful interpretation. This limitation, however, is attenuated by the inclusion of qualitative studies in the review and by the multivariate analysis of some quantitative studies. Additionally, there is need to interpret the findings carefully because most studies did not elaborate on whether the specific procedure paid for by SUS was actually covered by the PHI policy; one study 22 based on a household survey with national coverage found out that the percentage of utilization of SUS was similar between privately insured individuals and those whose policies actually covered the procedure (Supplementary Material, Table 3; http://cadernos.ensp.fiocruz.br/site/ public_site/arquivo/suppl-e00004118_2644.pdf). It is also necessary to be careful when generalizing the findings of this review beyond the context of the studies here included. While the authors of such studies conducted their research in a fairly favorable macroeconomic context and under a particular PHI regulation, during the drafting of this review Brazil faced an economic recession and its Ministry of Health was considering the implementation of a new modality of PHI, called "popular plans".

The findings of this review confirm that privately insured people prioritize their PHI's provider network, leaving SUS as a fallback. In other words, to the extent that SUS' services are duplicated by PHI, SUS becomes secondary to PHI for privately insured people, the opposite of what the official nomenclature for PHI in Brazil ("supplementary health") would imply 38. In Brazil, thus, PHI might shift some demand for health care from SUS, differently from what happens in the OECD countries 4,39. This is understandable given the differences in financing between SUS and the public health system of OECD countries with duplicate PHI. In 2014, according to GHED, public health expenditures in Brazil were of Int\$607 per capita (international dollars, adjusted for purchase power parity) or 3.8\% of the gross domestic product, much lower than expenditures in Spain (Int\$2,102; 6.4\%), Italy (Int $\$ 2,449 ; 7 \%$ ), Ireland (Int\$2,511; 5.1\%), United Kingdom (Int\$2,808; 7.6\%) or Australia (Int\$2,921; 6.3\%). While in these OECD countries access to health care is discussed in terms of time to elective surgical procedures 4,39, in Brazil, SUS does not ensure timely access even to the simplest outpatient consultations, in what has even been described as "institutional violence" 40.

No study included in this review tackled costs of the utilization of SUS by privately insured people. Even if the low utilization of SUS by privately insured people affects public sector's expenses, the net effect of duplicate PHI on the availability of resources for public health is not clear because, on 
the other hand, PHI also receives public resources as fiscal incentives or (for PHI sponsored by public employers) even budget allocation 5,41,42,43,44,45.

Beyond this unknown effect on the availability of public resources for SUS, duplicate PHI has been considered a limitation to the universal, equitable character of SUS 43,45,46. Considering privately insured people use preferentially their PHI's provider network, Brazil has a two-tiered health system, in which wealthier people have timely access to well financed health services that provide better care experiences, and poorer people receive care from not so well financed care services with organizational barriers and a less satisfactory care experiences, thus maintaining a situation of blatant socioeconomic inequity in health 1,40,46,47,48,49,50,51. Quantitatively, PHI has been shown to contribute to pro-rich horizontal (need-adjusted) inequities in medical consultations, dentist visits, hospitalization and care in general 52.

One might expect this socioeconomic inequity in health to decrease with the prohibition of duplicate PHI in Brazil 45. However, in this hypothetical scenario, it would be anything but trivial for SUS to accomodate privately insured people's expectancies on consumption of health services 45 . The challenge, thus, is to qualify the regulation of PHI, by turning its competitive relationship with SUS to a more collaborative relationship aiming at ensuring the social right to health $1,38,48,53$.

In short, the scientific literature on the utilization of SUS by privately insured people confirms SUS as playing a secondary in the health care of these people. This secondary role of SUS limits its universal, equitable character, leaving to the State the challenge of innovating PHI regulation. Future research should fill in the gaps identified in this review and investigate collaboration strategies between PHI and SUS.

\section{Contributors}

L. F. Fontenelle conceived and outlined the study, collected and interpreted the data, and drafted the manuscript. T. D. Sarti collected and verified the data and revised the manuscript. M. B. J. Camargo designed and delineated the study, interpreted the data and revised the manuscript. E. L. N. Maciel interpreted the data and revised the manuscript. A. J. D. Barros collaborated in the design and delineation of the study and in the interpretation of the results and revised the manuscript.

\section{Additional informations}

ORCID: Leonardo Ferreira Fontenelle (00000003-4064-433X); Thiago Dias Sarti (0000-00021545-6276); Maria Beatriz Junqueira de Camargo (0000-0001-7908-5999); Ethel Leonor Noia Maciel (0000-0003-4826-3355); Aluísio J. D. Barros (00000002-2022-8729).

\section{References}

1. Sekhri N, Savedoff W. Private health insurance: implications for developing countries. Bull World Health Organ 2005; 83:127-34.

2. Viacava F, Bellido JG. Health, access to services and sources of payment, according to household surveys. Ciênc Saúde Colet 2016; 21:35170.

3. Agência Nacional de Saúde Suplementar. Glossário temático: saúde suplementar. 2a Ed. Brasília: Ministério da Saúde; 2012.

4. Organisation for Economic Co-Operation and Development. Private health insurance in OECD countries. Paris: Organisation for Economic Co-Operation and Development; 2004 (The OECD Health Project).

5. Santos IS, Ugá MAD, Porto SM. O mix público-privado no sistema de saúde brasileiro: financiamento, oferta e utilização de serviços de saúde. Ciênc Saúde Colet 2008; 13:1431-40.

6. Ministério da Saúde; Organização Pan-Americana da Saúde; Associação Brasileira de Economia da Saúde. A produção de conhecimento em economia da saúde: uma perspectiva bibliográfica (2004-2012). Brasília: Ministério da Saúde; 2013.

7. Ministério da Saúde; Organização Pan-Americana da Saúde; Associação Brasileira de Economia da Saúde. Os Núcleos de Economia da Saúde: histórico e produção bibliográfica. Brasília: Ministério da Saúde; 2016. 
8. Bahia L. Mudanças e padrões das relações público-privado: seguros e planos de saúde no Brasil [Doctoral Dissertation]. Rio de Janeiro: Escola Nacional de Saúde Pública, Fundação Oswaldo Cruz; 1999.

9. Santos IS. Planos privados de assistência a saúde no mundo do trabalho [Masters' Thesis]. Rio de Janeiro: Escola Nacional de Saúde Pública, Fundação Oswaldo Cruz; 2000.

10. Silva NN, Pedroso GC, Puccini RF, Furlani WJ. Desigualdades sociais e uso de serviços de saúde: evidências de análise estratificada. Rev Saúde Pública 2000; 34:44-9.

11. Travassos C, Viacava F, Fernandes C, Almeida CM. Desigualdades geográficas e sociais na utilização de serviços de saúde no Brasil. Ciênc Saúde Colet 2000; 5:133-49.

12. Farias LO, Melamed C. Segmentação de mercados da assistência à saúde no Brasil. Ciênc Saúde Colet 2003; 8:585-98.

13. Viacava F, Souza-Júnior PRB, Szwarcwald CL. Coverage of the Brazilian population 18 years and older by private health plans: an analysis of data from the World Health Survey. Cad Saúde Pública 2005; 21 Suppl 1:S119-28.

14. Ribeiro MCSA, Barata RB, Almeida MF, Silva ZP. Perfil sociodemográfico e padrão de utilização de serviços de saúde para usuários e não -usuários do SUS - PNAD 2003. Ciênc Saúde Colet 2006; 11:1011-22.

15. Gerschman S, Veiga L, Guimarães C, Ugá MAD, Portela MC, Vasconcellos MM, et al. Estudo de satisfação dos beneficiários de planos de saúde de hospitais filantrópicos. Ciênc Saúde Colet 2007; 12:487-500.

16. Pessoto UC, Heimann LS, Boaretto RC, Castro IEN, Kayano J, Ibanhes LC, et al. Desigualdades no acesso e utilização dos serviços de saúde na Região Metropolitana de São Paulo. Ciênc Saúde Colet 2007; 12:351-62.

17. Barata RB. Acesso e uso de serviços de saúde: considerações sobre os resultados da Pesquisa de Condições de Vida 2006. São Paulo Perspect 2008; 22:19-29.

18. Barreto Jr. IF, Ferreira MP, Silva ZP. Pesquisa de condições de vida 2006: acesso aos serviços de saúde em áreas vulneráveis à pobreza. São Paulo Perspect 2008; 22:5-18.

19. Barros AJD, Santos IS, Bertoldi AD. Can mothers rely on the Brazilian health system for their deliveries? An assessment of use of the public system and out-of-pocket expenditure in the 2004 Pelotas Birth Cohort Study, Brazil. BMC Health Serv Res 2008; 8:57.

20. Conill EM, Pires D, Sisson MC, Oliveira MC, Boing AF, Fertonani HP. O mix público-privado na utilização de serviços de saúde: um estudo dos itinerários terapêuticos de beneficiários do segmento de saúde suplementar brasileiro. Ciênc Saúde Colet 2008; 13:1501-10.

21. Fernandes LCL, Bertoldi AD, Barros AJD. Health service use in a population covered by the Estratégia de Saúde da Família (Family Health Strategy). Rev Saúde Pública 2009; 43:595-603.
22. Oliveira CMF. Utilização de serviços do Sistema Único de Saúde por beneficiários de planos de saúde [Masters' Thesis]. Rio de Janeiro: Fundação Oswaldo Cruz; 2009.

23. Pereira RJ, Cotta RMM, Franceschini SCC, Ribeiro RCL, Tinoco ALA, Rosado LEFPL, et al. Análise do perfil sociossanitário de idosos: a importância do Programa de Saúde da Família. Rev Méd Minas Gerais 2010; 20:5-15.

24. Porto SM, Ugá MAD, Moreira RS. Uma análise da utilização de serviços de saúde por sistema de financiamento: Brasil 1998-2008. Ciênc Saúde Colet 2011; 16:3795-806.

25. Silva ZP, Ribeiro MCSA, Barata RB, Almeida MF. Perfil sociodemográfico e padrão de utilização dos serviços de saúde do Sistema Único de Saúde (SUS), 2003-2008. Ciênc Saúde Colet 2011; 16:3807-16.

26. Sisson MC, Oliveira MC, Conill EM, Pires D, Boing AF, Fertonani HP. Satisfação dos usuários na utilização de serviços públicos e privados de saúde em itinerários terapêuticos no sul do Brasil. Interface Comun Saúde Educ 2011; 15:123-36.

27. Bousquat A, Gomes A, Alves MCGP. Acesso realizado ao Programa de Saúde da Família em área com "alta" cobertura do subsistema privado. Ciênc Saúde Colet 2012; 17:2913-21.

28. Hernandes ESC, Lebrão ML, Duarte YAO, Santos JLF. Health insurance coverage of the elderly and socioepidemiological characteristics associated. Rev Saúde Pública 2012; 46:1030-8.

29. Oliveira LS, Almeida LGN, Oliveira MAS, Gil GB, Cunha ABO, Medina MG, et al. Acessibilidade a atenção básica em um distrito sanitário de Salvador. Ciênc Saúde Colet 2012; 17:304756.

30. Pires MRGM, Göttems LBD, Cupertino TV, Leite LS, Vale LR, Castro MA, et al. A utilização dos serviços de atenção básica e de urgência no SUS de Belo Horizonte: problema de saúde, procedimentos e escolha dos serviços. Saúde Soc 2013; 22:211-22.

31. Amorim VMSL, Barros MBA. Equity of access to Pap smears: population-based study in Campinas, São Paulo, Brazil. Rev Bras Epidemiol 2014; 17:136-49.

32. Bonello AADLM, Corrêa CRS. Acesso aos serviços básicos de saúde e fatores associados: estudo de base populacional. Ciênc Saúde Colet 2014; 19:4397-406.

33. Garcia-Subirats I, Vargas Lorenzo I, Mogollón-Pérez AS, Paepe PD, Ferreira da Silva MR, Unger JP, et al. Determinantes del uso de distintos niveles asistenciales en el Sistema General de Seguridad Social en Salud y Sistema Único de Salud en Colombia y Brasil. Gac Sanit 2014; 28:480-8.

34. Olsen JM. Uso de serviços segundo a posse de plano privado de saúde no município de São Paulo [Masters' Thesis]. São Paulo: Universidade de São Paulo; 2014. 
35. Santiago AX, Barreto ICHC, Sucupira ACSL, Lima JWO, Andrade LOM. Equitable access to health services for children aged 5 to 9 in a medium city of northeasth of Brazil: a result of Family Health Strategy. Rev Bras Epidemiol 2014; 17 Suppl 2:39-52.

36. Zanon LR, Zanin L, Flório FM. Evaluation of the use of services provided by emergency care units in a Brazilian municipality. Rev Gauch Odontol 2016; 64:411-8.

37. Arruda GO, Mathias TAF, Marcon SS. Prevalence and factors associated with the use of public health services for adult men. Ciênc Saúde Colet 2017; 22:279-90.

38. Sestelo JAF, Souza LEPF, Bahia L. Saúde suplementar no Brasil: abordagens sobre a articulação público/privada na assistência à saúde. Cad Saúde Pública 2013; 29:851-66.

39. Tuohy CH, Flood CM, Stabile M. How does private finance affect public health care systems? Marshaling the evidence from OECD nations. J Health Polit Policy Law 2004; 29:359-96.

40. Fleury S, Bicudo V, Rangel G, Soto Fors M, Mier Armas M, Rúa Martínez R, et al. Reacciones a la violencia institucional: estrategias de los pacientes frente al contraderecho a la salud en Brasil. Salud Colect 2013; 9:11-25.

41. Ocké-Reis CO. O Estado e os planos de saúde no Brasil. Revista do Serviço Público 2000; 51:124-47.

42. Andreazzi MFS, Ocké-Reis CO. Renúncia de arrecadação fiscal: subsídios para discussão e formulação de uma política pública. Physis (Rio J.) 2007; 17:521-44.

43. Bahia L. As contradições entre o SUS universal e as transferências de recursos públicos para os planos e seguros privados de saúde. Ciênc Saúde Colet 2008; 13:1385-97.

44. Viana ALD, Machado CV. Proteção social em saúde: um balanço dos 20 anos do SUS. Physis (Rio J.) 2008; 18:645-84.
45. Santos IS. Evidência sobre o mix público-privado em países com cobertura duplicada: agravamento das iniquidades e da segmentação em sistemas nacionais de saúde. Ciênc Saúde Colet 2011; 16:2743-52.

46. Travassos C, Oliveira EXG, Viacava F. Desigualdades geográficas e sociais no acesso aos serviços de saúde no Brasil: 1998 e 2003. Ciênc Saúde Colet 2006; 11:975-86.

47. Farias LO. Estratégias individuais de proteção à saúde: um estudo da adesão ao sistema de saúde suplementar. Ciênc Saúde Colet 2001; 6:405-16.

48. Ocké-Reis CO. Challenges of the private health plans regulation in Brazil. Rio de Janeiro: Instituto de Pesquisa Econômica Aplicada; 2004. (Texto para Discussão, 1013).

49. Drechsler D, Jütting J. Different countries, different needs: the role of private health insurance in developing countries. J Health Polit Policy Law 2007; 32:497-534.

50. Albuquerque C, Piovesan MF, Santos IS, Martins ACM, Fonseca AL, Sasson D, et al. A situação atual do mercado da saúde suplementar no Brasil e apontamentos para o futuro. Ciênc Saúde Colet 2008; 13:1421-30.

51. Gerschman S. Políticas comparadas de saúde suplementar no contexto de sistemas públicos de saúde: União Européia e Brasil. Ciênc Saúde Colet 2008; 13:1441-51.

52. Mullachery P, Silver D, Macinko J. Changes in health care inequity in Brazil between 2008 and 2013. Int J Equity Health 2016; 15:140.

53. Azevedo BDS, Biondo CS, Sena ELS, Boery RNSO, Yarid SD. Bioethical reflection regarding access to supplemental health in Brazil. Acta Bioeth 2015; 21:117-25. 


\section{Resumo}

Mais de um em cada quatro brasileiros têm planos de saúde, apesar de estes planos cobrirem majoritariamente os mesmos procedimentos do Sistema Único de Saúde (SUS). Esta revisão da literatura incluiu artigos e monografias publicados desde 1990 sobre a utilização do SUS por indivíduos com plano de saúde. Ao considerar conjuntamente a assistência ambulatorial e hospitalar, os brasileiros com planos de saúde utilizam o SUS em aproximadamente $13 \%$ das vezes em que recebem cuidados; aproximadamente $7 \%$ das pessoas que recebem cuidados pagos pelo SUS dispõem de planos de saúde (os achados variam de acordo com o tipo de serviço analisado e com os detalhes metodológicos dos estudos). O aumento da utilização do SUS está associado a: regiões menos desenvolvidas do país, planos de saúde com pior cobertura e pessoas com pior saúde. Os brasileiros com plano de saúde citam as limitações dos planos como o motivo pelo qual recorrem ao SUS. Em alguns casos os beneficiários de planos de saúde comercializados por hospitais filantrópicos (os quais também prestam assistência financiada pelo SUS) relatam acesso mais fácil à assistência financiada pelo SUS, comparado com aqueles sem plano de saúde. Pessoas com plano de saúde eventualmente citam a satisfação com a utilização do SUS, mas não a ponto do SUS se tornar a fonte de assistência preferida. Em resumo, para os brasileiros com plano de saúde, o SUS desempenha papel secundário no financiamento dos cuidados de saúde. Embora os planos de saúde pareçam deslocar parte da demanda por assistência para fora do SUS, esses mesmos planos tendem a restringir o caráter universal e equitativo do SUS.

Sistema Único de Saúde; Seguro Saúde; Assistência à Saúde; Serviços de Saúde

\section{Resumen}

Más de uno de cada cuatro brasileños tiene un seguro de salud privado (PHI), a pesar de que estos últimos cubren en su mayoría los mismos procedimientos que en el Sistema Unificado de Salud (SUS). Esta revisión de la literatura incluyó artículos y monografías publicadas desde 1990 sobre la utilización del SUS por parte de personas aseguradas mediante el sistema privado. Considerando atención ambulatoria junto a hospitalización, la población con seguro médico privado en Brasil utiliza el SUS aproximadamente un 13\% de las veces que reciben atención médica; además, aproximadamente un $7 \%$ de la gente que recibe atención médica pagada a través del SUS tiene seguro privado. Los resultados varían con el tipo de servicio estudiado y con los detalles de los métodos de estudio. La frecuencia de utilización del SUS es mayor en las regiones menos desarrolladas, por parte de la población con planes de seguros de salud más limitados, y personas con peor salud. Las personas con seguros privados identifican las limitaciones de sus planes PHI como la razón por la que usan el SUS. Algunas veces, los beneficiarios de los planes PHI de hospitales sin fines de lucro (que también proveen servicios de salud financiados por el SUS) cuentan con un acceso más sencillo a los cuidados de salud sufragados por el SUS que las personas sin seguro. Anecdóticamente, la población con seguro de salud privado está satisfecha con la utilización que hacen del SUS, pero no hasta el extremo de que el SUS se trasforme en su principal vía para recibir servicios médicos. En resumen, para la población con seguro privado, el SUS juega un papel secundario en la financiación de la asistencia a sus cuidados de salud. Pese a que el PHI parece desviar del SUS parte de la demanda de cuidados de salud, el PHI representa una restricción del carácter universal y equitativo del SUS.

Sistema Único de Salud; Seguro de Salud;

Prestación de Atención de Salud;

Servicios de Salud
Submitted on 09/Jan/2018

Final version resubmitted on 09/Jan/2019

Approved on 12/Feb/2019 